\title{
Humic Substances: Determining Potential Molecular Regulatory Processes in Plants
}

\author{
Zahid Hussain Shah ${ }^{1}$, Hafiz M. Rehman', Tasneem Akhtar ${ }^{1}$, Hameed Alsamadany ${ }^{3}$, \\ Bahget T. Hamooh', Tahir Mujtaba ${ }^{4}$, Ihsanullah Daur', Yahya Al Zahrani ${ }^{3}$, \\ Hind A. S. Alzahrani ${ }^{5}$, Shawkat Ali6, Seung H. Yang ${ }^{2}$ and Gyuhwa Chung ${ }^{2 *}$
}

1 Department of Arid Land Agriculture, King Abdulaziz University, Jeddah, Saudi Arabia, ${ }^{2}$ Department of Electronics and Biomedical Engineering, Chonnam National University, Gwangju, South Korea, ${ }^{3}$ Department of Biological Sciences, King Abdulaziz University, Jeddah, Saudi Arabia, ${ }^{4}$ Plant and Forest Biotechnology Umeå, Plant Science Centre, Swedish University of Agriculture Sciences, Umeå, Sweden, ${ }^{5}$ Department of Biology, College of Science, Imam Abdulrahman bin Faisal University, Dammam, Saudi Arabia, ${ }^{6}$ Kentville Research and Development Centre, Agriculture and Agri-Food Canada, Kentville, NS, Canada

\section{OPEN ACCESS}

Edited by:

Stefano Cesco,

Free University of Bozen-Bolzano, Italy

Reviewed by:

Serenella Nardi,

University of Padova, Italy

Riccardo Scotti,

Consiglio per la Ricerca in Agricoltura e l'Analisi dell'Economia Agraria

(CREA), Italy

${ }^{*}$ Correspondence:

Gyuhwa Chung

Chung@chonnam.ac.kr

Specialty section:

This article was submitted to

Plant Nutrition,

a section of the journal

Frontiers in Plant Science

Received: 01 November 2017

Accepted: 14 February 2018

Published: 13 March 2018

Citation:

Shah ZH, Rehman HM, Akhtar T,

Alsamadany $H$, Hamooh BT,

Mujtaba T, Daur I, Al Zahrani Y,

Alzahrani HAS, Ali S, Yang SH and

Chung G (2018) Humic Substances:

Determining Potential Molecular

Regulatory Processes in Plants.

Front. Plant Sci. 9:263.

doi: 10.3389/fpls.2018.00263
Humic substances (HSs) have considerable effects on soil fertility and crop productivity owing to their unique physiochemical and biochemical properties, and play a vital role in establishing biotic and abiotic interactions within the plant rhizosphere. A comprehensive understanding of the mode of action and tissue distribution of HS is, however, required, as this knowledge could be useful for devising advanced rhizospheric management practices. These substances trigger various molecular processes in plant cells, and can strengthen the plant's tolerance to various kinds of abiotic stresses. HS manifest their effects in cells through genetic, post-transcriptional, and post-translational modifications of signaling entities that trigger different molecular, biochemical, and physiological processes. Understanding of such fundamental mechanisms will provide a better perspective for defining the cues and signaling crosstalk of HS that mediate various metabolic and hormonal networks operating in plant systems. Various regulatory activities and distribution strategies of HS have been discussed in this review.

Keywords: humic acid, epigenetic modifications, genotoxicity, hormonal regulations, nod factors, signaling crosstalk

\section{INTRODUCTION}

Approximately $60 \%$ of soil organic matter consists of humic substances (HSs), which, as key components of the terrestrial ecosystem, are responsible for several complex chemical reactions in the soil (Trevisan et al., 2010). HS are supramolecular structures of heterogenous molecules comprising of sugar, fatty acids, polypeptides, aliphatic chains, and aromatic rings, held together by hydrophobic interactions (such as van der Waals, $\pi-\pi$, ion-dipole) and hydrogen bonds (Piccolo, 2001; Trevisan et al., 2010). HS have been classified into humin, humic acid and fulvic acid, based on different solubility at acid and alkaline $\mathrm{pH}$ (Trevisan et al., 2010). This classification is based only on superficial criteria, and does not indicate chemical behavior or provide insights into chemical structures.

Humus is main fraction of humic substances, and is typically prepared by successive steps of fermentation of garbage, agricultural by-products, fresh organic matter from plants, animals, and coal. Fermentation of these substances occurs via activity of soil microbiota under selected 
physio-molecular conditions such as controlled temperature, time, water, and aeration (Canellas and Olivares, 2014). Regardless of the source of origin of the carbon (i.e., C3 and C4), HS and humic acids extracted from the soil are structurally similar (Muscolo et al., 2013; García et al., 2016a). However, HS have wide and extensive functions in plants (Canellas et al., 2010; Canellas and Olivares, 2014). For example, many studies have shown that plants growing in soils with adequate HS content, or those exposed to foliar spray consisting of HS, are healthier; these plants cope well under stressful conditions, and produce high yields with enhanced nutritional quality. The most convincing demonstration of the effect of HS has been the report of their role in lateral root development and root hair formation (Ramos et al., 2015), which was evaluated by Khristeva (1957), a pioneer in this field of research. Moreover, several studies highlight various physiochemical and biological properties of $\mathrm{HS}$ to explain their significance in soil fertility (Hirel et al., 2007; Brown et al., 2014). However, considerable gaps still exist in our understanding of how HS induce signaling in plants that allows them to cope with heavy metal genotoxicity (Yigider et al., 2016), epigenetic modifications (Erturk et al., 2015), and building rhizospheres and microbial interactions (Gao et al., 2015). Moreover, the unique molecular structure of HS and their relative response to antioxidant, drought, and salt stresses has been reported to explain the biological effect of HS on plants (Canellas and Olivares, 2014); one such mechanism involves binding of HS with inorganic trace mineral elements that can then be utilized by various crop plants to trigger potential molecular processes. HS thus function as important ion exchange and metal complexing (chelating) molecules (Beiraghi et al., 2014). In this manner, HS can readily enter plant roots, stems, and leaves, and carry trace minerals from plant surfaces into plant tissues; for this reason, HS are used as key ingredients in high-quality foliar fertilizers (García et al., 2016a).

Similarly, HS, particularly those with a low molecular mass, are readily taken up by plants, and help promote nutrient uptake (Garcia-Mina et al., 2004), or plant growth and development, by acting as hormone-like substances (Vaughan and Malcom, 1985; Nardi et al., 2000, 2002). Likewise, HS also have a positive effect on other plant physiological processes such as leaf chlorophyll content (Vaughan and Malcom, 1985); however, the relationship between physio-molecular activity and biological activity of HS, because of their complex nature, is not as yet completely understood. These scientific highlights related to HS need to be linked with molecular function and reactivity, in order to gain a comprehensive understanding of their role in the functional and regulatory processes of plants.

This review specifically considers the actions of HS on various functional and regulatory processes of plants (e.g., signaling, mineral uptake, abiotic stress tolerance, mitigation of heavy metal genotoxicity, microbial activity, transport, etc.), involving both, their physiological and molecular impacts. The aim of this review is to highlight the roles of HS as an organic biostimulant and its physio-molecular aspects related to plant health.

\section{Humic Substances and Improved Mineral Nutrition}

The presence of HS in soil stimulates the growth of root and shoot by improving mineral nutrition beneath the soil surface. The activity of these substances can be evaluated in terms of the yield and active growth of plants (Zandonadi et al., 2016). HS regulate plant growth and mineral assimilation through their complementary and potentially diverse effects. These effects are generally categorized as direct and indirect (Vaughan and Malcom, 1985; Zandonadi et al., 2013). Activities of HS are primarily dependent upon structural features, functional groups, and their tendency to interact with inorganic and organic ions and molecules residing in the soil substrate (Garcia-Mina et al., 2004). Moreover, HS mainly affect nutrient bioavailability via their ability to form complexes with metallic ions, which enhances the availability of micronutrients (zinc, manganese, copper, and iron); and macronutrients (phosphorus), and particularly when these nutrients are scarce in the soil (García et al., 2016b). Conversely, direct action of HS is related to their localized targeted and non-targeted effects at plant cell membranes, that can initiate biochemical and molecular processes at post-transcriptional levels in roots and shoots (Van Oosten et al., 2017). Generally, targeted effects of HS tend to enhance the uptake of macronutrients and micronutrients in plants. Vaughan and Malcom (1985) used 14-C labeled HS, and found that a minor fraction of these substances, specifically those with lower molecular weight, enter into the root apoplastic pathway. Hence, this feature can regulate the action of HS in promoting the uptake of nutrients by molecular systems and signaling pathways present in root cell membranes (Asli and Neumann, 2010; García et al., 2012; Nardi et al., 2016). Until now, the complete benefit of this type of direct effect is not yet known. It can however be speculated that non-specific action of HS on the leaf or root surface can alter molecular and biochemical processes by regulating the events at both transcriptional and post-transcriptional levels.

\section{Humic Substances and Abiotic Stress Regulation}

Mitigating the effects of abiotic stresses on the growth and development of plants during ontogenesis can significantly benefit the productivity of crop plants. Current knowledge about the controlling mechanisms and strategies is limited (Van Oosten et al., 2017). Optimization of plant growth conditions and provision of water, nutrients, and plant growth regulators can help in preventing abiotic stresses (García et al., 2014). In addition to these conventional strategies, biostimulants like HS are frequently being integrated into production systems with the objective of regulating physiological events in plants to increase the productivity. HS derived from natural materials have gained increasing use by scientists in the last two decades (Yakhin et al., 2016). Moreover, HS provide novel approaches for modifying physiological activities in plants to improve plant growth and resistance toward abiotic stresses. 
Various examples indicate the capability of HS to increase abiotic stress tolerance in plants. HS treatment of bent grass (Agrostis palustris) and fescue (Festuca arundinacea) increased leaf hydration, antioxidant ability, root growth, and shoot growth under dry soil conditions (Zhang and Ervin, 2008; Van Oosten et al., 2017). Recent studies have revealed that fouling-mediated transient blockage of cell wall pores is responsible for the effects caused by HS, which could potentially be associated with a transient mild water stress (a beneficial stress, 'eustress') and is responsible for downstream HS-mediated effects on hormonal signaling pathways and plant development (Olaetxea et al., 2015). Integrated application of HS and seaweed extract increases drought tolerance, as well as endogenous levels of cytokinins (Zhang and Ervin, 2008). Similarly, augmentation of humic acid with phosphorus deceased sodium content in bell pepper (Capsicum annuum L. 'Demre'), but increased levels of nitrogen, phosphorus, potassium, iron, magnesium, sulfur, manganese, and copper contents in roots and shoots, which are indicators of the protective effect of HS against salinity stress (Çimrin et al., 2010). Furthermore, Aydin et al. (2012) observed that HS application under saline conditions increased proline content, and reduced membrane leakage and reactive oxygen species (ROS) generation in the common bean (Phaseolus vulgaris L.), reflecting better adaptability to saline conditions. Similar to their beneficial effects on field crop dicots, HS are also equally beneficial to field crop monocots (Van Oosten et al., 2017). Vermi-compost applications to rice (Oryza sativa L.) dynamically increased the concentration of ROS scavenging enzymes and triggered the activity of anti-oxidative enzymes. These enzymes play a crucial role for inactivation of oxygen free radicals generated in plants under drought and salinity stress (García et al., 2012). Moreover, HS differentially regulate proton ATPases located in vacuolar and cell membranes that ultimately mitigate the hazardous effects of ROS. Correspondingly, when tomato plants were subjected to vermi-compost, the extrusion of protons from the plasma membrane was exceeded by $40 \%$, which increased acid formation and nutrient uptake tendency (Zandonadi et al., 2016). Interestingly, a decrease in proton exclusion was observed in an auxin insensitive mutant of tomato, and indicates that HS may trigger root growth by regulating auxin signaling (Zandonadi et al., 2016). Relatively few studies have explained the physiological effect of HS on the molecular aspects of crop plants. For example, in maize, an isoform of $\mathrm{H}^{+}$-ATPase MHA2 gene works as a specific auxin target, and a phospholipase A2 gene (Russell et al., 2006; Canellas et al., 2010, 2011; Pizzeghello et al., 2012) acts as a component of auxin-dependent signaling.

\section{Prevention of Heavy Metal Genotoxicity and Genetic Instability}

Humic substances mitigate the effects of surplus heavy metals that can trigger genotoxicity and genetic instability. Although heavy metals play a vital role as essential micronutrients in several physiological processes of plants (i.e., respiration, photosynthesis, and protein synthesis) by modulating the biological mechanisms of various proteins and enzymes (Erturk et al., 2015), they can nonetheless cause toxicity under extremely high concentrations
(Nardi et al., 2007; Aguirre et al., 2009). Recent reports have shown various toxic effects of heavy metals on several plant metabolic processes.

Several heavy metals are mutagenic elements, and their genotoxicity has been demonstrated in various mutagenic assays (Doroftei et al., 2010; Erturk et al., 2012a,b). The synthesis of ROS (i.e., $1 \mathrm{O}_{2}, \mathrm{O}^{2-}, \mathrm{OH}^{-}$, and $\mathrm{H}_{2} \mathrm{O}_{2}$ ) might increase the genotoxic effects of these metals (Li et al., 2010), since ROS destroy proteins, nucleic acids, and lipids in a pervasive manner (Erturk et al., 2015). The protective role of HS is primarily related to their association with glutathione biosynthesis, which protects DNA and other cellular entities from the oxidative damage of free radicals. Many authors have reported that the toxic effects of heavy metals can likely be ameliorated by HS (Haghighi et al., 2010), because HS function as antitoxic, anticlastogenic, and antimutagenic agents (Marova et al., 2011). Likewise, a protective effect of HA against dicamba-induced genotoxicity and DNA modification in Phaseolus vulgaris L. has been reported by Yildirim et al. (2014). To date, no comprehensive reports exist regarding the retrotransposonal changes caused by heavy metals and DNA mutations in plants. Therefore, investigation of the polymorphic (insertion) role of retroelements and genomic instability in crops under heavy metal stress, coupled with the effects of HA on these polymorphisms, is needed.

Humic substance establish transcriptional interactions with biochemical components and signaling pathways, eliciting dynamic signaling crosstalk inside the plant to cope with various types of stresses (García et al., 2016a). For example, epigenetic modifications such as methylation, alkylation, oxidation, DNA strand breakage, and cross linkage in proteins take place due to the adverse effects of oxidative damage caused by heavy metals (Guangyuan et al., 2007; Erturk et al., 2015). Although plants have evolved various antioxidant defense mechanisms to counter such damage (Apel and Hirt, 2004; Madsen-Bouterse et al., 2010), heavy metals trigger various epigenetic mechanisms, including DNA methylation, histone modification, and the expression of non-coding RNAs (Erturk et al., 2015) that regulate gene expression in multiple ways, especially under stress conditions (Cheng et al., 2012). It has been reported that gene expression has significant correlations with epigenetic modifications such as DNA hypo- and hyper-methylation; likewise, various biological pathways (i.e., transcriptional gene silencing and transposable element inactivation) are also linked with phylogenetic developments (Cheng et al., 2012; Büyükkeskin et al., 2014).

Humic substances are thought to play a role in restricting retrotransposon activity, limiting excessive genomic changes (Picault et al., 2009). Plants have complex genomes with large amounts of inactive transposable elements (TEs) and a few trans-positionally active TEs (Casacuberta and Gonzalez, 2013). Various stresses, including those caused by heavy metals, are responsible for increasing retrotransposon activity (Picault et al., 2009). Although TE-generated mutations are vital for environmental adaption, active transposable elements might cause potentially harmful genetic modifications and mutations, leading to genomic instability (Casacuberta and Gonzalez, 2013). Therefore, plants have also evolved processes that can suppress 
TE activity (Pecinka et al., 2010). Yigider et al. (2016) reported that Mn exhibits a dynamic role in inducing epigenetic changes in Zea mays; however, its effect is countered by HA treatments at different doses. In fact, the protective action of HS is associated with their antioxidant and enzyme-regulatory actions, which are reflected in the reduced expression of TEs (Picault et al., 2009; Yigider et al., 2016). HS augment the tolerance of plants to heavy metal toxicity (Table 1) by coordinating the actions of non-enzymatic antioxidants and ROS-detoxification enzymes.

\section{Humic Substances: Signaling, Regulatory, Antioxidant, and Physiological Roles in Roots}

The biological activity of HS has been extensively investigated for many years, but comprehensive and uniform knowledge of HS activity still needs to be integrated into a single model (Mora et al., 2014). The extant results indicate that HS trigger effect-oriented action via involvement of different but integrated mechanisms, which function as sequential events of complex networks at transcriptional and post-transcriptional levels (Garcia-Mina et al., 2004; Mora et al., 2014). HS exhibit direct effect-mediated actions, such as the interaction of rhizospheric HS with plant roots. Despite some reports on the possible penetration of the HS fraction into the root apoplast and epidermal cell layer, conclusive results have not yet been obtained (Mora et al., 2014). However, some biological effects of HS on plant activities (Table 1) are obvious, as their physical accumulation cannot be ruled out in plant root and shoot systems due to their reported presence on the root surface (Olaetxea et al., 2015). Moreover, HS play a significant role in mediating signaling, regulatory, and physiological events in roots.

Recent studies have also described the vital role of increased root hydraulic conductance, triggered by abscisic acid (ABA) and aquaporin gene expression, during shoot growth enhancement caused by applications of sedimentary humic acid (SHA) to roots (García et al., 2014; Olaetxea et al., 2015). However, data on the role of HS-mediated increase in ROS in root and shoot systems are yet to be obtained (García et al., 2016a). In general, these findings suggest that interconnected signaling pathways and physiological events play an essential role in shoot growth processes, stimulated by humic acid with sedimentary origin (Mora et al., 2012). Micromorphological and macromorphological effects are identified as two prominent and direct effects of HS on root development (Trevisan et al., 2010, 2011; Mora et al., 2012). Micromorphological effects are manifested by an increase in absorbent hairs and lateral roots, whereas macromorphological effects are observed as an increase in root dry weight, secondary root number, and primary and secondary root thickness. Many reports identify the HA derived from vegetal residues as a root-proliferation enhancer at later developmental stages, which modifies the root architecture (Canellas and Olivares, 2014). This is further linked with activation of root $\mathrm{PM}-\mathrm{H}^{+}$-ATPase activity, via auxin [indole acetic acid (IAA)] activity and possibly through NO (nitric oxide)-dependent pathways (Canellas et al., 2002; Zandonadi et al., 2010).
Genes encoding different metabolic pathways responsible for nutrient uptake and upregulation of auxin biosynthesis pathways, help mediate the effects in the roots of corn, tomato, and Arabidopsis (Zandonadi et al., 2010; Ramos et al., 2015). The superstructure organization of HA helps explain their effects. For example, various reports explain both the presence and activity of HA in rhizosphere, where it releases structural fragments or molecules to accelerate auxin bioactivity (Canellas and Olivares, 2014). Low concentrations of several hormones have been clearly observed in composted fresh vegetal material (Olaetxea et al., 2015). Various studies have also reported that root development is affected by the activity of relevant phytoregulators that are mediated by the presence of HS near the root system (Jannin et al., 2012; Mora et al., 2014; Olaetxea et al., 2015).

Moreover, HS, in association with signaling agents and their accessory entities, regulate various processes within plant cells, as shown in Table 2. These data consequently point toward the potential role of other factors in HS-mediated thickening of roots, increase in dry weight, and secondary root development (Olaetxea et al., 2015; García et al., 2016b). For example, these results highlight scenarios where hormone (auxin and ETH)-dependent pathways could not explain the effect on root structure of the water-soluble fraction of peat-derived HS (Trevisan et al., 2010; Zandonadi et al., 2010). Analytical studies on phytoregulators in HS found that the concentrations of these compounds were under the detection limit (Pizzeghello et al., 2012). Thus, reports that HS hormones or hormonelike structural domains are present in the HA superstructure, particularly during the interaction of HS with cell walls, can only be considered as a viable (and likely testable) hypothesis at this point.

Frequently, ROS and $\mathrm{Ca}^{2+}$ signals work collectively in association with protein kinases and protein phosphorylation to regulate post-translational events (Shabala et al., 2016). Moreover, the $\mathrm{Ca}^{2+}$-kinase signaling route plays a vital role in elucidating the targeted effects of HS in root development (Ramos et al., 2015). HS-activated signaling pathways are identified at the post-transcriptional level during calcium-dependent protein phosphorylation (Ramos et al., 2015). The process of protein phosphorylation and the role of $\mathrm{Ca}^{2+}$-dependent protein kinase activity are reported to be compatible with the pathways in the post-transcriptional expression of HS activity (Ramos et al., 2015; Shabala et al., 2016).

The internal region of the cell remains inaccessible to most HS. However, HS can positively affect the plasma membrane (PM) $\mathrm{H}^{+}$-ATPase-driven enzyme expression and proton gradients, and thus can hypothetically serve as a useful biological marker (Cordeiro et al., 2011a,b). It is speculated that root PM receptors sense HS to produce IAA, which not only activate transcription factors and protein metabolism, but also modulate the activity of $\mathrm{PM} \mathrm{H} \mathrm{H}^{+}$-ATPase to trigger cell division and growth. Moreover, in maize roots, a high uptake of nitrogen is associated with the upregulation of the transcripts of PM $\mathrm{H}^{+}$-ATPase and $\mathrm{NO}_{2}$ transporters (Cordeiro et al., 2011b). Canellas et al. (2002) have reported that the mitotic precursors possess twofold higher concentrations of $\mathrm{PM} \mathrm{H}^{+}$-ATPase in the lateral roots of maize, compared to the control. Quaggiotti 
TABLE 1 | Humic substance (HS)-triggered mode of action and alterations that regulate specific activities in plants to mitigate stresses.

\begin{tabular}{|c|c|c|c|c|}
\hline Mechanisms & Plants & Alterations & Functions & Reference \\
\hline $\begin{array}{l}\text { Photosynthesis and energy } \\
\text { metabolism }\end{array}$ & $\begin{array}{l}\text { Agrostis tenuis, Arabis } \\
\text { paniculata, Lonicera } \\
\text { japonica, Pteris vittata }\end{array}$ & $\begin{array}{l}\text { Abundance of } \\
\text { photosynthetic proteins of } \\
\text { the cytochrome b6/f } \\
\text { complex, OEC, RuBisCO, } \\
\text { ATPase in green tissues }\end{array}$ & $\begin{array}{l}\text { Detoxification of heavy } \\
\text { metals }\end{array}$ & Visioli and Marmiroli, 2013 \\
\hline $\begin{array}{l}\text { Protein and nitrogen } \\
\text { metabolism }\end{array}$ & $\begin{array}{l}\text { Alyssum lesbiacum, } A \text {. } \\
\text { paniculata, B. juncea, } P \text {. } \\
\text { americana }\end{array}$ & $\begin{array}{l}\text { Modulation and induction of } \\
\text { specific proteins }\end{array}$ & $\begin{array}{l}\text { Detoxification of heavy } \\
\text { metals and prevention } \\
\text { against biotic stress }\end{array}$ & $\begin{array}{l}\text { Bona et al., 2011; } \\
\text { García et al., 2016b }\end{array}$ \\
\hline Sulfur sequestration & $\begin{array}{l}\text { Alyssum lesbiacum, } A . \\
\text { thaliana, Brassica napus }\end{array}$ & Modulation of proteins & $\begin{array}{l}\text { Detoxification of heavy } \\
\text { metals and ROS } \\
\text { scavenging }\end{array}$ & Schneider et al., 2013 \\
\hline Defense protein triggering & $\begin{array}{l}\text { Alyssum bertolonii, } N \text {. } \\
\text { caerulescens, } P \text {. vittata }\end{array}$ & $\begin{array}{l}\text { Disruption of the cellular } \\
\text { redox status }\end{array}$ & $\begin{array}{l}\text { Detoxification of heavy } \\
\text { metals, ROS scavenging, } \\
\text { abiotic and biotic stress } \\
\text { tolerance }\end{array}$ & DalCorso et al., 2013 \\
\hline Membrane trafficking & $\begin{array}{l}\text { A. thaliana, A. halleri, N. } \\
\text { caerulescens }\end{array}$ & $\begin{array}{l}\text { Activation of ATPase and } \\
\text { ionic pumps residing in } \\
\text { membrane }\end{array}$ & $\begin{array}{l}\text { Sequestration of metal ions } \\
\text { into vacuoles and other } \\
\text { sub-cellular compartments, } \\
\text { and their export across the } \\
\text { membranes }\end{array}$ & $\begin{array}{l}\text { DalCorso et al., 2013; } \\
\text { Schneider et al., } 2013\end{array}$ \\
\hline Metal ligation & $\begin{array}{l}\text { A. lesbiacum, N. } \\
\text { caerulescen, P. americana }\end{array}$ & $\begin{array}{l}\text { Abundance of small } \\
\text { cysteine-rich metal-binding } \\
\text { proteins and constitutive } \\
\text { expression of respective } \\
\text { genes }\end{array}$ & $\begin{array}{l}\text { Detoxification of heavy } \\
\text { metals }\end{array}$ & $\begin{array}{l}\text { Bona et al., 2011; } \\
\text { Ramos et al., } 2015\end{array}$ \\
\hline
\end{tabular}

TABLE 2 | Humic substance associated signaling activities in plants.

\begin{tabular}{|c|c|c|c|c|}
\hline $\begin{array}{l}\text { Signaling } \\
\text { agents }\end{array}$ & Accessory entities & Regulatory processes & Indicators & Reference \\
\hline Auxins & $\begin{array}{l}\text { Auxin-responsive promoters } \\
(D R 5: \text { uidA and BA3: uidA, } \\
\text { ABP1, and TMK) }\end{array}$ & $\begin{array}{l}\text { Alter root morphology, by } \\
\text { increasing the root surface } \\
\text { through auxin-independent } \\
\text { signaling pathways }\end{array}$ & IAA, ETH, or NO & Mora et al., 2012 \\
\hline ROS & $\begin{array}{l}\text { Activity of the enzymes } \\
\text { peroxidase (POX), ascorbate } \\
\text { peroxidase (APOX), catalase } \\
\text { (CAT), and superoxide } \\
\text { dismutase (SOD) }\end{array}$ & $\begin{array}{l}\text { Regulation of oxidative } \\
\text { metabolism, as well as } \\
\text { increasing the levels of } \mathrm{H}_{2} \mathrm{O}_{2} \\
\text { and decreasing lipid } \\
\text { peroxidation, possibly via the } \\
\text { transformation and control } \\
\text { exercised by enzymes }\end{array}$ & $\mathrm{IAA}, \mathrm{NO}$, and ETH & $\begin{array}{l}\text { García et al., 2014, } \\
2016 a\end{array}$ \\
\hline $\mathrm{ABA}$ & $\begin{array}{l}\mathrm{H}_{2} \mathrm{O}_{2} \text { production and } \mathrm{Ca}^{2+} \\
\text { channel signaling, plasma } \\
\text { membrane intrinsic protein (PIP) }\end{array}$ & $\begin{array}{l}\text { Regulation of root hydraulic } \\
\text { conductivity, in the shoot } \\
\text { growth promoting action and } \\
\text { plant development }\end{array}$ & OsTIP1;2 & $\begin{array}{l}\text { Olaetxea et al., } \\
2015\end{array}$ \\
\hline Aquaporins & $\begin{array}{l}\text { Genes of the tonoplast intrinsic } \\
\text { aquaporin (TIP) subfamily }\end{array}$ & $\begin{array}{l}\text { Osmoregulation and water flow } \\
\text { through tonoplasts }\end{array}$ & IAA, NO & Ramos et al., 2015 \\
\hline $\mathrm{Ca}^{2+}$ gradient & $\begin{array}{l}\text { NADPH oxidase, } \\
\text { calcium-dependent protein } \\
\text { kinase (CPDK) }\end{array}$ & $\begin{array}{l}\text { Regulation of other important } \\
\text { processes, including anti-stress } \\
\text { regulation and hormone } \\
\text { signaling, and cell wall } \\
\text { acidification }\end{array}$ & $\begin{array}{l}\text { OsCPK7, } \\
\text { OsCPK17 }\end{array}$ & García et al., 2016a \\
\hline
\end{tabular}

et al. (2004) similarly reported eightfold higher concentrations of mRNA (MHA2 transcripts) in lateral roots of maize, compared with the control. Humus interferes with the physiology and biochemistry of plants, putatively due to its accessorial contents like hormones, enzymes, and transporters (García et al., 2014).
Receptors in the cell membrane sense HS in the rhizosphere to produce IAA, which increases the concentration of NO in root cells. Moreover, NO modulates the gene expression to elicit three growth-triggering pathways. The first pathway activates the generation of alkaloids (ALK), cytokinin (CK), gibberellic acid (GA), and polyamines (PA), which 
upregulate the nitrate transporter $\left(\mathrm{NO}_{3} \mathrm{~T}\right)$ to maximize nitrogen assimilation. The second pathway upregulates the activity of $\mathrm{PM} \mathrm{H} \mathrm{H}^{+}$-ATPase that pumps out $\mathrm{H}^{+}$into the cell wall, causing its acidification and loosening. The third pathway generates proteins whose over-expression upregulates the tonoplast enzymes, $\mathrm{V}$-ATPase and $\mathrm{H}^{+}$-PPase, to initiate the influx of auxin and $\mathrm{H}^{+}$into the vacuole. Moreover, other processes such as energy metabolism, protein metabolism, and biotic responses are also triggered in root cells by HS (Figure 1).

\section{Humic Substances: Signaling Crosstalk and Root-Shoot Physiological Events}

Several studies have authenticated the ability of HS to regulate root and shoot physiological events. However, the mechanisms of HS action remain unknown (Olaetxea et al., 2016). Various signaling entities such as ABA, nitrate, NO, ROS, and IAA dynamically regulate the root and shoot physiological events by triggering several pathways in response to HS, as shown in Figure 2. The various signaling and regulatory components of HS-mediated crosstalk are described in the following subsections.
Humic acid accelerates shoot growth via various processes in the root and shoot, such as $\mathrm{PM} \mathrm{H}^{+}$-ATPase activity, which is directly related to the production of a gene isoform (Cs-HA2). The upregulation of these isoforms is strongly correlated with an increase in the root-to-shoot mobility of activated forms of cytokinins and nitrates (Mora et al., 2010; Gao et al., 2012). The root-to-shoot translocation of both micro- and macro-mineral nutrients also increased due to the signaling effect of nitrate. This effect is associated with cytokinin sink action in the shoot system (Mora et al., 2010; Ramos et al., 2015).

Humic acid triggers an increase in the levels of IAA and NO, which promote shoot growth action; ethylene is also generated in roots, but remains inactive (Mora et al., 2012, 2014). In roots, the application of HS elicits the NO-IAA signaling pathway, which increases the concentration of ABA (Mora et al., 2014). Moreover, high concentrations of sedimentary HS in the rhizosphere reduce hydraulic conductivity in roots, thus, inhibiting plant shoot growth and blocking water uptake by roots (Hose et al., 2000). This is attributed to the accumulation of HA in the pores of the cell wall at the root surface (Asli and Neumann, 2010). Under some experimental scenarios, it was observed that the root hydraulic conductivity is regulated by $\mathrm{ABA}$, where it affects

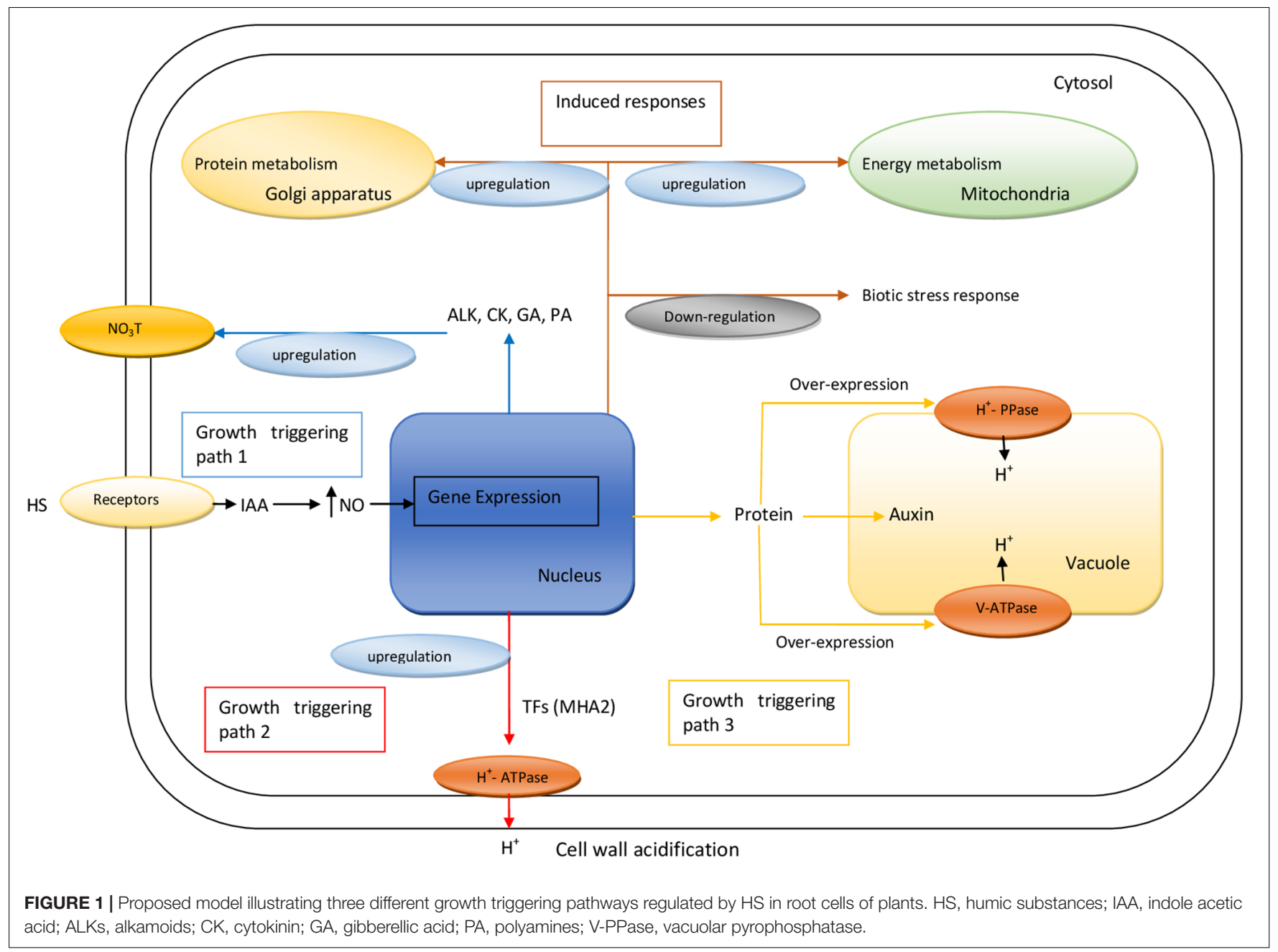




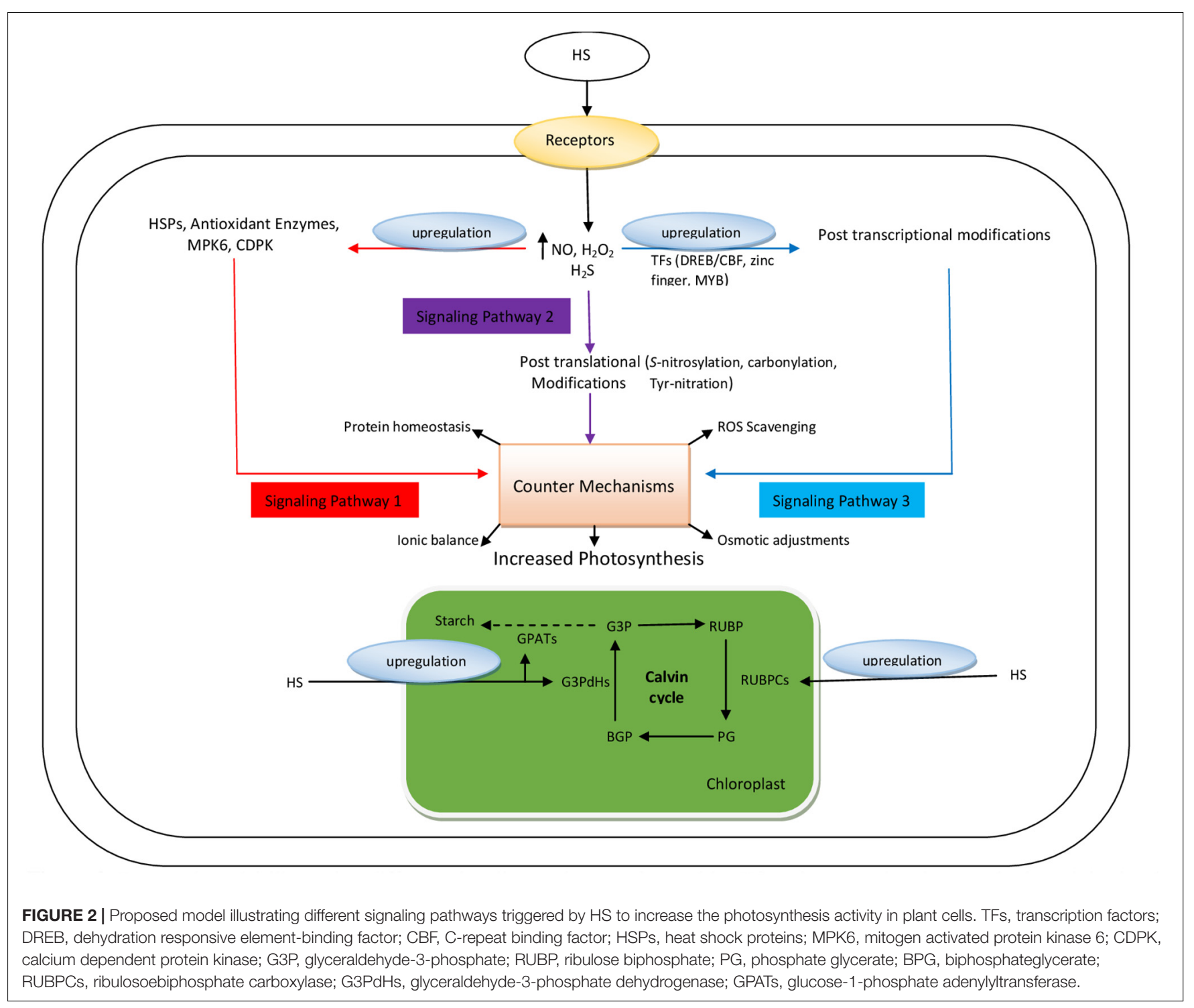

the aquaporin activity of plasma membrane directly (Hose et al., 2000). Therefore, it can be concluded that aquaporin activity and water uptake by the roots is controlled by the rhizospheric concentrations of HS.

The use of ABA-inhibitor fluoridone in combination with HS inhibits root growth, root hydraulic conductivity, and shoot growth. In general, the beneficial impact of $\mathrm{HS}$ on shoot development is functionally attributed to IAA, NO, and ABA signaling pathways (Mora et al., 2010). Moreover, these agents regulate the activity of $\mathrm{PM} \mathrm{H}^{+}$-ATPase via proteins (Takahashi et al., 2012). It can be speculated that interconnected hormonemediated signaling pathways and the $\mathrm{PM} \mathrm{H}^{+}$-ATPase pathway together regulate the beneficial actions of HS on shoot growth. However, it is a striking fact that HAs obtained from both vegetal and sedimentary sources share the common domains of signaling pathways in roots (Canellas and Olivares, 2014). The significant impact of both kinds of HS on shoot development can be attributed to their similarity.
To date, numerous studies have been conducted to investigate the effects of HS on root and shoot development, but reports on signaling dynamics with a systems biology approach are scarce and limited. Consequently, more studies are required to further explore this concept. Following the cue, recent reports have demonstrated that the interconnected signaling networks triggered by $\mathrm{HS}$ in root and shoot cells likely include ROS signaling pathways (García et al., 2012). HAs derived from vermicomposted vegetal residues are not only able to regulate root development in rice, but also modulate the ROS homeostasis (García et al., 2016a). These properties are connected with transcriptional and post-transcriptional events that modulate the enzymatic activity during oxidative metabolism via their coordinated actions (Takahashi et al., 2012). Consequently, these findings are not surprising, as several studies have unraveled the signaling functions of primary and secondary ROS. As a secondary messenger, ROS mediates root development and architecture, as well as plant responses against biotic and abiotic 
stresses, by inducing hormonal action through NO and ABA (Cordeiro et al., 2011b). This study speculates that the production and accumulation of ROS is due to HA, and that an antioxidative enzyme network is needed for modulating the final concentration of ROS (Cordeiro et al., 2011a). Lateral root proliferation is supported by the signaling role of ROS, as there is a crucial role played by HA-mediated balance between ROS production and ROS scavenging. Interestingly, an association between HAmediated effect on ROS homeostasis and root dry weight was reported for rice roots; however, an increase in the hormonal concentrations of IAA, NO, or ETH does not explain this effect (Mora et al., 2012; García et al., 2014; Olaetxea et al., 2016). These studies describe the involvement of two pathways, i.e., hormonedependent and ROS-dependent effects of HS activity on the root phenotype.

Studies on cucumber sedimentary humic acid obtained from leonardite have also shown that cytokinin and root-to-shoot translocation of mineral nutrients play an important role during shoot growth and development (Mora et al., 2010; Orsi, 2014); however, this effect was associated with an increase in $\mathrm{PM} \mathrm{H}^{+}$ATPase activity and root-to-shoot translocation of nitrate (Mora et al., 2010, 2014). Significant improvement in photosynthetic pathways has been reported in rapeseed upon root application of an SHA obtained from black peat (Jannin et al., 2012). A consistent pattern was found among the physiological effects of SHA, thus upregulating the gene clusters controlling all of the above-mentioned physiological pathways such as photosynthesis, CK signaling perception, and N, S, and C metabolisms (Jannin et al., 2012). The shoot growth-promoting action of SHA in cucumber was found to be dependent on the increase in IAA and $\mathrm{NO}$ concentrations in roots caused by SHA root application (Mora et al., 2014).

Receptors located in the cell membrane can detect HS, which in turn increases the intracellular concentrations of $\mathrm{NO}, \mathrm{H}_{2} \mathrm{O}_{2}$, and $\mathrm{H}_{2} \mathrm{~S}$ (Jannin et al., 2012). These elevated concentrations initiate three pathways via post-translational, post-transcriptional, and gene-regulatory modifications, which trigger various homeostatic mechanisms in the plant cell for accelerating the rate of photosynthesis (Orsi, 2014). Moreover, HS upregulate the genes involved in the Calvin cycle, such as genes coding for RUBPCs, G3PdHs, and GPATs, thus increasing starch biosynthesis by stimulating photosynthetic activity (Figure 2).

\section{Humic Substances: Metabolic Activities and Distribution in Tissues}

Humic substance plays a vital role in establishing biotic and abiotic interactions within the plant rhizosphere (Kulikova et al., 2014, 2016). However, a comprehensive understanding of the mode of action and tissue distribution of HS is still needed, as this knowledge could then be applied for devising advanced rhizospheric management practices (Kulikova et al., 2016). This section focuses on a discussion of various regulatory activities of HS and its distribution in plant tissues.

Current research on HS is focused on their specific role in metabolic reactions of plants at targeted sites (Table 3). Many enzymes have been recognized that participate in different plant responses toward HS, such as Fe (III) chelate-reductase (Kulikova et al., 2014), $\mathrm{H}^{+}$-pyrophosphatase (Zancani et al., 2009), plasma membrane $\mathrm{H}^{+}$-ATPase (Quaggiotti et al., 2004), tricarboxylic acid cycle enzymes (Kulikova et al., 2016), and glycolytic enzymes (Canellas et al., 2015). It is concluded that HS have multiple regulating functions in plants (Table 3 ), including direct root growth stimulation and proliferation of root hair, maintenance of ion-uptake rates, regulation of the release of protons, redox reactions, and modulation of root exudates (Trevisan et al., 2010; Canellas et al., 2015).

Further research is however needed to explain the primary actions of HS. A transcriptomic technique was used to study the primary mode of action of HS (Trevisan et al., 2010, 2011). The expression of 133 genes primarily responsible for transport and catalytic activities, as well as for binding processes, is affected by HS in Arabidopsis thaliana (García et al., 2016b). Researchers assumed that HS affect plant growth and other processes via their involvement in the transcription of genes responsible for the formation and organization of the meristem, and organization of microtubules, cytokinesis, and the cell cycle. For this purpose, a directed focus on the entry of HS in roots, their internal transport, and spatial distribution within the plant parts is needed.

A previous study assessed the uptake of HS in plants using synthetic HA with a 14-C label (Vaughan and Ord, 1981). This study concluded that both low- and high-weight fractions of HS can be translocated by plants, but the low-weight fraction showed more penetration than the high-weight HS. This was confirmed by testing the effect of HS conjugated with fluorescein isothiocyanate (FITC) in cultured carrot cells (Muscolo et al., 2007). It was observed that only light-weight HS can be transported across the plasma membrane of carrot cells. In recent studies, tritium-labeled HS have been used to demonstrate the accumulation of labeled material in the roots of wheat seedlings, and its translocation into the shoot (Kulikova et al., 2014). The lipid portion of the treated seedlings was extracted and analyzed, and the tritium label was found in the neutral part of the lipids consisting of alkenes and alkanes that are generally present in waxes and linked with suberized and cuticle tissues. The direct effect of HS on the biosynthesis of lipids in plants, however, remains unclear.

\section{Humic Substances: Priming Symbiosis and Nodulation}

It is widely accepted that HS can accelerate the germination of seeds (Traversa et al., 2013), stimulate ATPase activity, and increase the utilization of nutrients by plants; moreover, HS can also mimic auxin-like hormone activity to promote the growth of plants (Canellas et al., 2010; Jannin et al., 2012). It is a well-accepted fact that the low quality of soil carbon limits the amount of energy available for soil microorganisms. In this case, priming the soil with HS causes an increase in microbial activity due increased availability of energy required by microbes. However, the mechanisms underlying such priming effects are much more complex than commonly believed. Tilba and Sinegovskaya (2012) reported that priming of soybean seeds (under field conditions) with rhizobia, sodium humate, 
TABLE 3 | Humic substance regulating activities in different crops.

\begin{tabular}{|c|c|c|c|c|c|}
\hline $\begin{array}{l}\text { Humic } \\
\text { substances }\end{array}$ & Enhanced activities & Crop & Target site & Functions & Reference \\
\hline $\begin{array}{l}\mathrm{HA}, \mathrm{FA} \text {, and } \\
\text { water-soluble } \\
\text { fractions }\end{array}$ & $\begin{array}{l}\text { Xanthine and xanthine-oxidase } \\
\text { system }\end{array}$ & Zea mays & Leaves, flowers & $\begin{array}{l}\text { Defense mechanisms against } \\
\text { biotic and abiotic stress from } \\
\text { heavy metals }\end{array}$ & $\begin{array}{l}\text { Cordeiro et al., } \\
\text { 2011b; García } \\
\text { et al., 2016a }\end{array}$ \\
\hline $\begin{array}{l}\text { HA from manure } \\
\text { vermi-compost }\end{array}$ & $\begin{array}{l}\text { Tonoplast aquaporin genes } \\
\text { (OsTIPs) }\end{array}$ & Oryza sativa & Leaves & $\begin{array}{l}\text { Lipid peroxidation and nitrogen } \\
\text { metabolism }\end{array}$ & García et al., 2012 \\
\hline FA & $\begin{array}{l}\text { Auxin signaling and } \\
\text { homeostasis, } \mathrm{H}^{+} \text {-ATPase, } \\
\text { NADPH oxidases, and MPK3 }\end{array}$ & $\begin{array}{l}\text { Arabidopsis } \\
\text { thaliana }\end{array}$ & Roots & $\begin{array}{l}\text { Membrane hyperpolarization, } \\
\text { activation of } \mathrm{Ca}^{2+} \text { channels, } \\
\text { and intracellular signaling to } \\
\text { increase the growth of } \\
\text { secondary roots }\end{array}$ & $\begin{array}{l}\text { Blomster et al., } \\
2011\end{array}$ \\
\hline $\mathrm{HA}, \mathrm{FA}$, and $\mathrm{HU}$ & Chlorophyllases (a) and (b) & $\begin{array}{l}\text { Pachira } \\
\text { macrocarpa }\end{array}$ & Leaves & $\begin{array}{l}\text { Stimulate the photosynthetic } \\
\text { activity and augment the } \\
\text { chlorophyll content and } \\
\text { conductance of mesophyll cells }\end{array}$ & $\begin{array}{l}\text { Haghighi et al., } \\
2012\end{array}$ \\
\hline HA & Chlorophyllases (a) and (b) & Lactuca sativa L. & Leaves & $\begin{array}{l}\text { Stimulate the photosynthetic } \\
\text { activity and augment the } \\
\text { chlorophyll content }\end{array}$ & $\begin{array}{l}\text { García et al., 2012; } \\
\text { Haghighi et al., } \\
2012\end{array}$ \\
\hline $\mathrm{HA}, \mathrm{FA}$ & $\begin{array}{l}\text { Phosphoenolpyruvate } \\
\text { carboxykinase (PEPC), } \\
\text { glutamate dehydrogenase } \\
\text { (GDH), MDH, and glutamine } \\
\text { synthetase (GS) }\end{array}$ & Pinus nigra & $\begin{array}{l}\text { Fruit, leaves } \\
\text { and flowers }\end{array}$ & $\begin{array}{l}\text { Activation of carbon and } \\
\text { nitrogen metabolism }\end{array}$ & $\begin{array}{l}\text { Jannin et al., 2012; } \\
\text { Olaetxea et al., } \\
2015\end{array}$ \\
\hline $\mathrm{HU}$ and $\mathrm{HA}$ & $\begin{array}{l}\text { Phenylalanine ammonia lyase } \\
(\mathrm{PAL}) \text { and tyrosine ammonia } \\
\text { lyase (TAL) }\end{array}$ & Brassica napus & $\begin{array}{l}\text { Flowers, roots, } \\
\text { and leaves }\end{array}$ & $\begin{array}{l}\text { Triggers nitrogen, sulfur and } \\
\text { carbon metabolism }\end{array}$ & García et al., 2012 \\
\hline HU and FA & Phospholipase A 2, ABA & Pisum sativum & Leaves & Regulate stomatal opening & Huang et al., 2013 \\
\hline $\mathrm{FA}, \mathrm{HA}$ & Peroxidases & Phaseolus vulgaris L. & & $\begin{array}{l}\text { Regulation of plant growth and } \\
\text { development, as well as the } \\
\text { assimilation of mineral elements } \\
\text { such as phosphorus and } \\
\text { nitrogen }\end{array}$ & Aydin et al., 2012 \\
\hline $\mathrm{HU}, \mathrm{FA}, \mathrm{HA}$ & Peroxidase, ABA & $\begin{array}{l}\text { Lycopersicon } \\
\text { esculentum L. }\end{array}$ & $\begin{array}{l}\text { Fruit, leaves } \\
\text { and roots }\end{array}$ & $\begin{array}{l}\text { Rise in proline content, } \\
\text { protection from hydraulic } \\
\text { stress, improvement in growth } \\
\text { and development of the plants, } \\
\text { even under drought conditions }\end{array}$ & $\begin{array}{l}\text { Hernández et al., } \\
\text { 2012; } \\
\text { Ramos et al., } 2015\end{array}$ \\
\hline
\end{tabular}

ammonium molybdate, and sodium humate leaf spraying, significantly increased the efficiency of nitrogen fixation and the number of nodules, resulting in an increase in crop yield of up to $22 \%$, compared with the control. Dong et al. (2009) reported that the application of HAs increased the yield of soybean by up to $26.4 \%$ and enhanced bacterial diversity, which was further promoted by urea application in the soil. The exact mechanism of the contribution of HAs toward the nitrogen fixation process is still ambiguous. Thus, this review provides a conceptual model of the effects of HS as a priming agent.

Many studies have established that HS can increase the number of rhizobia exponentially to stimulate nitrogen fixation in the soil, thus greatly benefiting sustainable agriculture. Moreover, it is also known that symbiotic rhizobia associations in agricultural systems could lead to the generation of 40 million tons of nitrogen each year (Udvardi and Poole, 2013). Gao et al. (2015) reported that the differential protein expression of soybean in response to water-soluble HS was related to energy production, nucleic acid metabolism, carbon metabolism, and some transmembrane transportation. In addition, HS were found to be more effective than genistein in triggering the expression of nod genes (Ahmad et al., 2012). Canellas et al. (2013) reported that HAs modulate metabolic processes in plants, such as enhancement of $\mathrm{PM} \mathrm{H}^{+}$-ATPase activity, alteration of sugar and $\mathrm{N}$ metabolism, and also induce greater net photosynthesis. Moreover, they reported an increase in the number of rhizobia when inoculation was performed in the presence of soluble HS.

\section{CONCLUSION}

Humic substances are plant tonic, and modulate the physiological and biochemical processes of plants by triggering multiple interconnected signaling pathways. Although the morphological effects of HS on plants have been comprehensively investigated, the molecular and biochemical basis of these effects still warrant further research. Crops treated with HS are highly tolerant to environmental stresses. To detect HS-plant interactions, priority should be given to increasing our understanding of 
functional mechanisms that render the highest impact on abiotic stress protection. HS establish transcriptional interactions with biochemical components and signaling pathways, eliciting dynamic signaling crosstalk inside the plant to cope with various types of stresses (Pecinka et al., 2010). Therefore, modeling the role of HS in plants could be a useful tool in filling this knowledge gap. Moreover, HS alleviate the risks of retroelements and genetic instability due to heavy metal stress in plants, and this feature could be a new target for future research. Significant phenotypic effects have been observed in the roots of plants upon HS application at both micro- and macro-morphologic levels (Ramos et al., 2015). Although some reports failed to explain the macro-morphological effects of HS in controlling hormonal increase in plants, these effects are expected to be associated with hormonal regulation, i.e., an increase in IAA, ethylene (ETH), NO, and ABA concentrations in roots (García et al., 2016b). On the other hand, HS are believed to play

\section{REFERENCES}

Aguirre, E., Leménager, D., Bacaicoa, E., Fuentes, M., Baigorri, R., Zamarreño, A. M., et al. (2009). The root application of a purified leonardite humic acid modifies the transcriptional regulation of the main physiological root responses to Fe deficiency in Fe-sufficient cucumber plants. Plant Physiol. Biochem. 47, 215-223. doi: 10.1016/j.plaphy.2008.11.013

Ahmad, M., Zahir, Z. A., Asghar, H. N., and Arshad, M. (2012). The combined application of rhizobial strains and plant growth promoting rhizobacteria improves growth and productivity of mung bean (Vigna radiata L.) under saltstressed conditions. Ann. Microbiol. 62, 1321-1330. doi: 10.1007/s13213-0110380-9

Apel, K., and Hirt, H. (2004). Reactive oxygen species: metabolism, oxidative stress, and signal transduction. Annu. Rev. Plant Biol. 55, 373-399. doi: 10.1146/ annurev.arplant.55.031903.141701

Asli, S., and Neumann, P. M. (2010). Rhizosphere humic acid interacts with root cell walls to reduce hydraulic conductivity and plant development. Plant Soil 336, 313-322. doi: 10.1007/s11104-010-0483-2

Aydin, A., Kant, C., and Turan, M. (2012). Humic acid application alleviates salinity stress of bean (Phaseolus vulgaris L.) plants decreasing membrane leakage. Afr. J. Agric. Res. 7, 1073-1086. doi: 10.5897/AJAR10.274

Beiraghi, A., Pourghazi, K., and Amoli-Diva, M. (2014). Mixed supramolecular hemimicelles aggregates and magnetic carrier technology for solid phase extraction of ibuprofen in environmental samples prior to its HPLC-UV determination. Chem. Eng. Sci. 108, 103-110. doi: 10.1016/j.ces.2013.12.044

Blomster, T., Salojärvi, J., Sipari, N., Brosché, M., Ahlfors, R., Keinänen, M., et al. (2011). Apoplastic reactive oxygen species transiently decrease auxin signaling and cause stress-induced morphogenic response in Arabidopsis. Plant Physiol. 157, 1866-1883. doi: 10.1104/pp.111.181883

Bona, E., Marsano, F., Massa, N., Cattaneo, C., Cesaro, P., Argese, E., et al. (2011). Proteomic analysis as a tool for investigating arsenic stress in Pteris vittata roots colonized or not by arbuscular mycorrhizal symbiosis. J. Proteomics 74, 1338-1350. doi: 10.1016/j.jport.2011.03.027

Brown, A. L., Jackson, W. R., and Cavagnaro, T. R. (2014). A meta-analysis and review of plant-growth response to humic substances: practical implications for agriculture. Adv. Agron. 124, 37-89. doi: 10.1016/B978-0-12-800138-7. 00002-4

Büyükkeskin, T., Akinci, Ş., and Eroğlu, A. E. (2014). The effects of humic acid on root development and nutrient uptake of Vicia faba L. (Broad Bean) seedlings grown under aluminum toxicity. Commun. Soil Sci. Plant Anal. 46, 277-292. doi: 10.1080/00103624.2014.969402

Canellas, L. P., Balmori, D. M., Médici, L. O., Aguiar, N. O., Campostrini, E., Rosa, R. C., et al. (2013). A combination of humic substances and Herbaspirillum seropedicae inoculation enhances the growth of maize (Zea mays L.). Plant Soil 366, 119-132. doi: 10.1007/s11104-012-1382-5 a vital role in the nodulation process, but questions remain as to their specific role(s), as no comprehensive data are as yet available. Researchers have used whole plants for analyses, instead of specific parts or tissues of plants, and therefore, specific detailed knowledge of the impacts of HS on plant physiology is yet to be gained (Matas et al., 2011). As a result, data on the spatial distribution of HS in the tissues and cells of plants, obtained through genetic studies, would be quite valuable.

\section{AUTHOR CONTRIBUTIONS}

ZHS and HMR generated the idea for this paper and wrote the manuscript, while HA, BTH, TM, TA, HASA, and YAZ searched the literature. ID and SA critically reviewed, while SY and GC proofread the manuscript.

Canellas, L. P., Dantas, D. J., Aguiar, N. O., Peres, L. E. P., Zsögön, A., Olivares, F. L., et al. (2011). Probing the hormonal activity of fractionated molecular humic components in tomato auxin mutants. Ann. Appl. Biol. 159, 202-211. doi: 10.1111/j.1744-7348.2011.00487.x

Canellas, L. P., and Olivares, F. L. (2014). Physiological responses to humic substances as plant growth promoter. Chem. Biol. Technol. Agric. 1, 1-11. doi: 10.1186/2196-5641-1-3

Canellas, L. P., Olivares, F. L., Aguiar, N. O., Jones, D. L., Nebbioso, A., Mazzei, P., et al. (2015). Humic and fulvic acids as biostimulants in horticulture. Sci. Hortic. 196, 15-27. doi: 10.1016/j.scienta.2015.09.013

Canellas, L. P., Olivares, F. L., Okorokova-Façanha, A. L., and Façanha, A. R. (2002). Humic acids isolated from earthworm compost enhance root elongation, lateral root emergence, and plasma membrane $\mathrm{H}+$-ATPase activity in maize roots. Plant Physiol. 130, 1951-1957. doi: 10.1104/pp.007088

Canellas, L. P., Piccolo, A., Dobbss, L. B., Spaccini, R., Olivares, F. L., Zandonadi, D. B., et al. (2010). Chemical composition and bioactivity properties of sizefractions separated from a vermicompost humic acid. Chemosphere 78, 457466. doi: 10.1016/j.chemosphere.2009.10.018

Casacuberta, E., and Gonzalez, J. (2013). The impact of transposable elements in environmental adaptation. Mol. Ecol. 22, 1503-1517. doi: 10.1111/mec.12170

Cheng, T. F., Choudhuri, S., and Muldoon-Jacobs, K. (2012). Epigenetic targets of some toxicologically relevant metals. J. Appl. Toxicol. 32, 643-653. doi: 10.1002/ jat. 2717

Çimrin, K. M., Türkmen, Ö., Turan, M., and Tuncer, B. (2010). Phosphorus and humic acid application alleviate salinity stress of pepper seedling. Afr. J. Biotechnol. 9, 5845-5851.

Cordeiro, F. C., Santa-Catarina, C., Silveira, V., and De-Souza, S. R. (2011a). Humic acid effect on catalase activity and the generation of reactive oxygen species in corn (Zea mays L). Biosci. Biotechnol. Biochem. 75, 70-74. doi: 10.1271/bbb. 100553

Cordeiro, F. C., Santa-Catarina, C., Silveira, V., and De-Souza, S. R. (2011b). ROS signaling: the new wave? Trends Plant Sci. 16, 300-309. doi: 10.1016/j.pbi.2011. 07.014

DalCorso, G., Fasani, E., and Furini, A. (2013). Recent advances in the analysis of metal hyperaccumulation and hypertolerance in plants using proteomics. Front. Plant Sci. 4:280. doi: 10.3389/fpls.2013.00280

Dong, L., Córdova-Kreylos, A. L., Yang, J., Yuan, H., and Scow, K. M. (2009). Humic acids buffer the effects of urea on soil ammonia oxidizers and potential nitrification. Soil Biol. Biochem. 41, 1612-1621. doi: 10.1016/j.soilbio.2009. 04.023

Doroftei, E., Antofie, M. M., Sava, D., and Arcuş, M. (2010). Cytogenetic effects induced by manganese and lead microelements on germination at Allium cepa. Bot. Serb. 34, 115-121.

Erturk, F. A., Agar, G., Arslan, E., and Nardemir, G. (2015). Analysis of genetic and epigenetic effects of maize seeds in response to heavy metal ( $\mathrm{Zn})$ 
stress. Environ. Sci. Pollut. Res. 22, 10291-10297. doi: 10.1007/s11356-0143886-4

Erturk, F. A., Agar, G., Arslan, E., Nardemir, G., and Bozari, S. (2012a). Molecular determination of genotoxic effects of manganese (Mn) on maize (Zea mays L.) by RAPD. J. Biotechnol. 161:31. doi: 10.1016/j.jbiotec.2012.07.087

Erturk, F. A., Ay, H., Nardemir, G., and Agar, G. (2012b). Molecular determination of genotoxic effects of cobalt and nickel on maize (Zea mays L.) by RAPD and protein analyses. Toxicol. Ind. Health 29, 662-671. doi: 10.1177/ 0748233712442709

Gao, G. T., Xu, Y. Y., Jiang, F., Li, B. Z., Yang, J. S., Wang, E. T., et al. (2015). Nodulation characterization and proteomic profiling of Bradyrhizobium liaoningense CCBAU05525 in response to water-soluble humic materials. Sci. Rep. 5:10836. doi: 10.1038/srep10836

Gao, T. G., Jiang, F., Yang, J. S., Li, B. Z., and Yuan, H. L. (2012). Biodegradation of Leonardite by an alkali-producing bacterial community and characterization of the degraded products. Appl. Microbiol. Biotechnol. 93, 2581-2590. doi: 10. 1007/s00253-011-3669-5

García, A. C., de Souza, L. G. A., Pereira, M. G., Castro, R. N., García-Mina, J. M., Zonta, E., et al. (2016a). Structure-property-function relationship in humic substances to explain the biological activity in plants. Sci. Rep. 6:e20798. doi: $10.1038 /$ srep 20798

García, A. C., Santos, L. A., de Souza, L. G. A., Tavares, O. C. H., Zonta, E., Gomes, E. T. M., et al. (2016b). Vermicompost humic acids modulate the accumulation and metabolism of ROS in rice plants. J. Plant Physiol. 192, 56-63. doi: $10.1155 / 2016 / 3747501$

García, A. C., Santos, L. A., Izquierdo, F. G., Rumjanek, V. M., Castro, R. N., dos Santos, F. S., et al. (2014). Potentialities of vermicompost humic acids to alleviate water stress in rice plants (Oryza sativa L.). J. Geochem. Explor. 136, 48-54. doi: 10.1016/j.gexplo.2013.10.005

García, A. C., Santos, L. A., Izquierdo, F. G., Sperandio, M. V. L., Castro, R. N., and Berbara, R. L. L. (2012). Vermicompost humic acids as an ecological pathway to protect rice plant against oxidative stress. Ecol. Eng. 47, 203-208.

Garcia-Mina, J. M., Antolín, M. C., and Sanchez-Diaz, M. (2004). Metal-humic complexes and plant micronutrient uptake: a study based on different plant species cultivated in diverse soil types. Plant Soil 258, 57-68. doi: 10.1023/b: plso.0000016509.56780.40

Guangyuan, L., Xiaoming, W., Biyun, C., Gao, G., and Kun, X. (2007). Evaluation of genetic and epigenetic modification in rapeseed (Brassica napus) induced by salt stress. J. Integr. Plant Biol. 49, 1599-1607. doi: 10.1111/j.1774-7909.2007. 00566.x

Haghighi, M., Kafi, M., and Fang, P. (2012). Photosynthetic activity and N metabolism of lettuce as affected by humic acid. Int. J. Veg. Sci. 18, 182-189. doi: 10.1080/19315260.2011.605826

Haghighi, M., Kafi, M., Fang, P., and Gui-Xiao, L. (2010). Humic acid decreased hazardous of cadmium toxicity on lettuce (Lactuca sativa 1.). Veg. Crop Res. Bull. 72, 49-61. doi: 10.2478/v10032-010-0005-z

Hernández, R., García, A., Portuondo, L., Muñiz, S., Berbara, R., and Izquierdo, F. (2012). Protección antioxidativa de los ácidos húmicos extraídos de vermicompost en arroz (Oryza sativa L.) var. IACuba30. Rev. Prot. Veg. 27, $102-110$.

Hirel, B., Le Gouis, J., Ney, B., and Gallais, A. (2007). The challenge of improving nitrogen use efficiency in crop plants: towards a more central role for genetic variability and quantitative genetics within integrated approaches. J. Exp. Bot. 58, 2369-2387. doi: 10.1093/jxb/erm097

Hose, E., Steudle, E., and Hartung, W. (2000). Abscisic acid and hydraulic conductivity of maize roots: a study using cell- and root-pressure probes. Planta 211, 874-882. doi: 10.1007/s004250000412

Huang, A. X., She, X. P., Zhang, Y. Y., and Zhao, J. L. (2013). Cytosolic acidification precedes nitric oxide removal during inhibition of $\mathrm{ABA}$ induced stomatal closure by fusicoccin. Russ. J. Plant Physiol. 60, 60-68. doi: 10.1134/ S1021443712060076

Jannin, L., Arkoun, M., Ourry, A., Laîné, P., Goux, D., Garnica, M., et al. (2012). Microarray analysis of humic acid effects on Brassica napus growth: involvement of N, C and S metabolisms. Plant Soil 359, 297-319. doi: 10.1007/ s11104-012-1191-x

Khristeva, L. A. (1957). "Stimulating activity of humic acid towards higher plants and the nature of this phenomenon," in Humic Fertilizers. Theory and Practice of Their Application (Kharkiv: Gorky State University), 75-93. doi: 10.1016/ S0960-8524(02)00017-2

Kulikova, N. A., Abroskin, D. P., Badun, G. A., Chernysheva, M. J., Korobkov, V. I., Beer, A. S., et al. (2016). Label distribution in tissues of wheat seedlings cultivated with tritium-labeled leonardite humic acid. Sci. Rep. 6:28869. doi: $10.1038 /$ srep 28869

Kulikova, N. A., Badun, G. A., Korobkov, V. I., Chernysheva, M. G., Tsvetkova, E. A., Abroskin, D. P., et al. (2014). Accumulation of coal humic acids by wheat seedlings: direct evidence using tritium autoradiography and occurrence in lipid fraction. J. Plant Nutr. Soil Sci. 177, 875-883. doi: 10.1002/jpln.201300648

Li, Q., Chen, L. S., Jiang, H. X., Tang, N., Yang, L. T., Lin, Z. H., et al. (2010). Effects of manganese-excess on $\mathrm{CO}_{2}$ assimilation, ribulose-1, 5-bisphosphate carboxylase/oxygenase, carbohydrates and photosynthetic electron transport of leaves, and antioxidant systems of leaves and roots in Citrus grandis seedlings. BMC Plant Biol. 10:42. doi: 10.1186/1471-2229-10-42

Madsen-Bouterse, S. A., Zhong, Q., Mohammad, G., Ho, Y. S., and Kowluru, R. A. (2010). Oxidative damage of mitochondrial DNA in diabetes and its protection by manganese superoxide dismutase. Free Radic. Res. 44, 313-321. doi: $10.3109 / 10715760903494168$

Marova, I., Kucerik, J., Duronova, K., Mikulcova, A., and Vlckova, Z. (2011). Antimutagenic and/or genotoxic effects of processed humic acids as tested upon S. cerevisiae $\mathrm{D}_{7}$. Environ. Chem. Lett. 9, 229-233. doi: 10.1007/s10311-0090270-6

Matas, A. J., Yeats, T. H., Buda, G. J., Zheng, Y., Chatterjee, S., Tohge, T., et al. (2011). Tissue- and cell-type specific transcriptome profiling of expanding tomato fruit provides insights into metabolic and regulatory specialization and cuticle formation. Plant Cell 23, 3893-3910. doi: 10.1105/tpc.111.091173

Mora, V., Bacaicoa, E., Baigorri, R., Zamarreno, A. M., and Garcia-Mina, J. M. (2014). NO and IAA key regulators in the shoot growth promoting action of humic acid in Cucumis sativus L. J. Plant Growth Regul. 33, 430-439. doi: 10.1007/s00344-013-9394-9

Mora, V., Bacaicoa, E., Zamarreño, A. M., Aguirre, E., Garnica, M., Fuentes, M., et al. (2010). Action of humic acid on promotion of cucumber shoot growth involves nitrate-related changes associated with the root-to-shoot distribution of cytokinins, polyamines and mineral nutrients. J. Plant Physiol. 167, 633-642. doi: 10.1016/j.jplph.2009.11.018

Mora, V., Baigorri, R., Bacaicoa, E., Zamarreño, A. M., and García-Mina, J. M. (2012). The humic acid-induced changes in the root concentration of nitric oxide, IAA and ethylene do not explain the changes in root architecture caused by humic acid in cucumber. Environ. Exp. Bot. 76, 24-32. doi: 10.1016/j. envexpbot.2011.10.001

Muscolo, A., Sidari, M., Francioso, O., and Nardi, S. (2007). The auxin-like activity of humic substances is related to membrane interactions in carrot cell cultures. J. Chem. Ecol. 33, 115-129. doi: 10.1007/s10886-006-9206-9

Muscolo, A., Sidari, M., and Nardi, S. (2013). Humic substance: relationship between structure and activity. Deeper information suggests univocal findings. J. Geochem. Explor. 129, 57-63. doi: 10.1016/j.gexplo.2012.10.012

Nardi, S., Concheri, G., Pizzeghello, D., Sturaro, A., Rella, R., and Parvoli, G. (2000). Soil organic matter mobilization by root exudates. Chemosphere 41, 653-658. doi: 10.1016/S0045-6535(99)00488-9

Nardi, S., Muscolo, A., Vaccaro, S., Baiano, S., Spaccini, R., and Piccolo, A. (2007). Relationship between molecular characteristics of soil humic fractions and glycolytic pathway and krebs cycle in maize seedlings. Soil Biol. Biochem. 39, 3138-3146. doi: 10.1016/j.soilbio.2007.07.006

Nardi, S., Pizzeghello, D., Muscolo, A., and Vianello, A. (2002). Physiological effects of humic substances on higher plants. Soil Biol. Biochem. 34, 1527-1536. doi: 10.1016/S0038-0717(02)00174-8

Nardi, S., Pizzeghello, D., Schiavon, M., and Ertani, A. (2016). Plant biostimulants: physiological responses induced by protein hydrolyzed-based products and humic substances in plant metabolism. Sci. Agric. 73, 18-23. doi: 10.1590/01039016-2015-0006

Olaetxea, M., Mora, V., Bacaicoa, E., Garnica, M., Fuentes, M., Casanova, E., et al. (2015). Abscisic acid regulation of root hydraulic conductivity and aquaporin gene expression is crucial to the plant shoot growth enhancement caused by rhizosphere humic acids. Plant Physiol. 169, 2587-2596. doi: 10.1104/pp.15. 00596

Olaetxea, M., Mora, V., Garcia, A. C., Santos, L. A., Baigorri, R., Fuentes, M., et al. (2016). Root-shoot signaling crosstalk involved in the shoot growth promoting 
action of rhizospheric humic acids. Plant Signal. Behav. 11:e1161878. doi: 10. $1080 / 15592324.2016 .1161878$

Orsi, M. (2014). Molecular dynamics simulation of humic substances. Chem. Biol. Technol. Agric. 1, 1-14. doi: 10.1186/s40538-014-0010-4

Pecinka, A., Dinh, H. Q., Baubec, T., Rosa, M., Lettner, N., and MittelstenScheid, O. (2010). Epigenetic regulation of repetitive elements is attenuated by prolonged heat stress in Arabidopsis. Plant Cell 22, 3118-3129. doi: 10.1105/ Tpc. 110.078493

Picault, N., Chaparro, C., Piegu, B., Stenger, W., Formey, D., Llauro, C., et al. (2009). Identification of an active LTR retrotransposon in rice. Plant J. 85, 754-765. doi: 10.1111/j.1365-313X.2009.03813.x

Piccolo, A. (2001). The supramolecular structure of humic substances. Soil Sci. 166, $810-832$.

Pizzeghello, D., Francioso, O., Ertani, A., Muscolo, A., and Nardi, S. (2012). Isopentenyladenosine and cytokinin-like activity of four humic substances. J. Geochem. Explor. 129, 103-111. doi: 10.1016/j.gexplo.2012.10.007

Quaggiotti, S., Ruperti, B., Pizzeghello, D., Francioso, O., Tugnoli, V., and Nardi, S. (2004). Effect of low molecular size humic substances on nitrate uptake and expression of genes involved in nitrate transport in maize (Zea mays L.). J. Exp. Bot. 55, 803-813. doi: 10.1093/jxb/erh085

Ramos, A. C., Dobbss, L. B., Santos, L. A., Fernandes, M. S., Olivares, F. L., Aguiar, N. O., et al. (2015). Humic matter elicits proton and calcium fluxes and signaling dependent on $\mathrm{Ca}^{2+}$-dependent protein kinase (CDPK) at early stages of lateral plant root development. Chem. Biol. Technol. Agric. 2:3. doi: 10.1186/s40538-014-0030-0

Russell, L., Stokes, A. R., Macdonald, H., Muscolo, A., and Nardi, S. (2006). Stomatal responses to humic substances and auxin are sensitive to inhibitors of phospholipase $A_{2}$. Plant Soil 283, 175-185. doi: 10.1007/s11104-0060011-6

Schneider, T., Persson, D. P., Husted, S., Schellenberg, M., Gehrig, P., Lee, Y., et al. (2013). A proteomics approach to investigate the process of $\mathrm{Zn}$ hyperaccumulation in Noccaea caerulescens. Plant J. 73, 131-142. doi: 10.1111/ 12022

Shabala, S., White, R. G., Djordjevic, M. A., Ruan, Y. L., and Mathesius, U. (2016). Root to-shoot signalling: integration of diverse molecules, pathways and functions. Funct. Plant Biol. 43, 87-104. doi: 10.1071/FP15252

Takahashi, K., Hayashi, K. I., and Kinoshita, T. (2012). Auxin activates the plasma membrane HC-ATPase by phosphorylation during hypocotyl elongation in arabidopsis. Plant Physiol. 159, 632-641. doi: 10.1104/pp.112. 196428

Tilba, V. A., and Sinegovskaya, V. T. (2012). Role of symbiotic nitrogen fixation in increasing photosynthetic productivity of soybean. Russ. Agric. Sci. 38, 361-363. doi: 10.3103/S1068367412050199

Traversa, A., Loffredo, E., Gattullo, C. E., Palazzo, A. J., Bashore, T. L., and Senesi, N. (2013). Comparative evaluation of compost humic acids and their effects on the germination of switchgrass (Panicum virgatum L.). J. Soil Sediments 14, 432-440. doi: 10.1007/s11368-013-0653-y

Trevisan, S., Botton, A., Vaccaro, S., Vezzaro, A., Quaggiotti, S., and Nardi, S. (2011). Humic substances affect Arabidopsis physiology altering the expression of genes involved in primary metabolism, growth and development. Environ. Exp. Bot. 74, 45-55. doi: 10.1016/j.envexpbot.2011.04.017

Trevisan, S., Francioso, O., Quaggiotti, S., and Nardi, S. (2010). Humic substances biological activity at the plant-soil interface: from environmental aspects to molecular factors. Plant Signal. Behav. 5, 635-643. doi: 10.4161/psb.5.6. 11211
Udvardi, M., and Poole, P. S. (2013). Transport and metabolism in legume-rhizobia symbioses. Annu. Rev. Plant Biol. 64, 781-805. doi: 10.1146/annurev-arplant050312-120235

Van Oosten, M. J., Pepe, O., De Pascale, S., Silletti, S., and Maggio, A. (2017). The role of biostimulants and bioeffectors as alleviators of abiotic stress in crop plants. Chem. Biol. Technol. Agric. 4:5. doi: 10.1186/s40538-017-0089-5

Vaughan, D., and Malcom, R. E. (1985). "Influence of humic substances on growth and physiological processes," in Soil Organic Matter and Biological Activity, eds D. Vaughan and R. E. Malcom (Dordrecht: Martinus Nijhoff), 37-76.

Vaughan, D., and Ord, B. G. (1981). Uptake and incorporation of 14C-labelled soil organic matter by roots of Pisum sativum L. J. Exp. Bot. 32, 679-687. doi: $10.1093 / \mathrm{jxb} / 32.4 .679$

Visioli, G., and Marmiroli, N. (2013). The proteomics of heavy metal hyperaccumulation by plants. J. Proteomics 79, 133-145. doi: 10.1016/j.jport. 2011.03.027

Yakhin, O. I., Lubyanov, A. A., Yakhin, I. A., and Brown, P. H. (2016). Biostimulants in plant science: a global perspective. Front. Plant Sci. 7:2049. doi: 10.3389/fpls. 2016.02049

Yigider, E., Taspinar, M. S., Sigmaz, B., Aydin, M., and Agar, G. (2016). Humic acids protective activity against manganese induced LTR (long terminal repeat) retrotransposon polymorphism and genomic instability effects in Zea mays. Plant Gene 6, 13-17. doi: 10.1016/j.plgene.2016.03.002

Yildirim, N., Agar, G., Taspinar, M. S., Turan, M., Aydin, M., and Arslan, E. (2014). Protective role of humic acids against dicamba-induced genotoxicity and DNA methylation in Phaseolus vulgaris L. Acta Agric. Scand. B Soil Plant Sci. 64, 141-148. doi: 10.1080/09064710.2014.891650

Zancani, M., Petrussa, E., Krajñáková, J., Casolo, V., Spaccini, R., Piccolo, A., et al. (2009). Effect of humic acids on phosphate level and energetic metabolism of tobacco BY-2 suspension cell cultures. Environ. Exp. Bot. 65, 287-295. doi: 10.1016/j.envexpbot.2008.09.012

Zandonadi, D. B., Santos, M. P., Busato, J. G., Peres, L. E. P., and Façanha, A. R. (2013). Plant physiology as affected by humified organic matter. Theor. Exp. Plant Physiol. 25, 13-25. doi: 10.1590/S2197-00252013000100003

Zandonadi, D. B., Santos, M. P., Caixeta, L. S., Marinho, E. B., Peres, L. E. P., Façanha, A. R., et al. (2016). Plant proton pumps as markers of biostimulant action. Sci. Agric. 73, 24-28.

Zandonadi, D. B., Santos, M. P., Dobbss, L. B., Olivares, F. L., Canellas, L. P., Binzel, M. L., et al. (2010). Nitric oxide mediates humic acids-induced root development and plasma membrane $\mathrm{H}^{+}$-ATPase activation. Planta 231, 1025-1030. doi: 10.1007/s00425-010-1106-0

Zhang, X., and Ervin, E. H. (2008). Impact of seaweed extract-based cytokinins and zeatin riboside on creeping bentgrass heat tolerance. Crop Sci. 48, 364-370.

Conflict of Interest Statement: The authors declare that the research was conducted in the absence of any commercial or financial relationships that could be construed as a potential conflict of interest.

Copyright (C) 2018 Shah, Rehman, Akhtar, Alsamadany, Hamooh, Mujtaba, Daur, AlZahrani, Alzahrani, Ali, Yang and Chung. This is an open-access article distributed under the terms of the Creative Commons Attribution License (CC BY). The use, distribution or reproduction in other forums is permitted, provided the original author(s) and the copyright owner are credited and that the original publication in this journal is cited, in accordance with accepted academic practice. No use, distribution or reproduction is permitted which does not comply with these terms. 